\title{
The learners perceive electronic feedback in writing multicultural class using Edmodo
}

\author{
Tazkiyatunnafs Elhawwa ${ }^{1}$, Dwi Rukmini ${ }^{2}$, Januarius Mujiyanto ${ }^{3}$, Djoko Sutopo ${ }^{4}$ \\ \{tazkiyatunnafs.elhawwa@gmail.com ${ }^{1}$,wiwidwirukmini@yahoo.com ${ }^{2}$, yanmujiyanto@gmail.com $^{3}$, \\ djokosutopo_msi@yahoo.com ${ }^{4}$ \} \\ Postgraduate of English Education Department, Universitas Negeri Semarang
}

\begin{abstract}
The study explores the learners' perceived of electronic feedback in writing multicultural class using Edmodo at the English Department of IAIN Palangka Raya. This is descriptive research. The participants are the L2 learners of three ethnic groups: Dayaknese, Banjarese, and Javanese, consisting of twenty-five learners. The instruments used to collect data are questionnaires and observation. The finding reveals that all ethnic group learners have a positive response on electronic feedback in an L2 writing class. Dealing with the types of feedback, most participants about ninety percent of dayaknese and eighty-six percent of Banjarese prefer to treat using electronic direct feedback. Meanwhile, Javanese about eighty-three percent prefer to treat using electronic indirect feedback. Dealing with the sources of feedback, most participants about ninety-two percent of Javanese and eighty percent of Banjarese prefer to be treated by teacher electronic feedback. Meanwhile, Dayaknese about eighty-one percent prefers to be treated by peer electronic feedback. It is suggested that language instructors pay attention to the students' cultural background in giving electronic feedback to learners.
\end{abstract}

Keywords: Perceive, electronic feedback, EFL multicultural class, Edmodo.

\section{Introduction}

Corrective feedback is pivotal in the L2 learning process (Goo \& Mackey, 2011; Li, 2010; Russell \& Spada, 2006; Saito \& Lyster, 2012). Specifically, feedback enables the L2 teachers to give more information on the accuracy of learners' writing products by increasing awareness of the grammatical errors of L2 writing. Electronic feedback becomes researchers' attention and interest (Prins, Slujismans, Kirschner \& Strijbos, 2005; Tuzi, 2004; and Chen, 1997) for many years. Electronic feedback is digital feedback that is recorded using computer technology (Tuzi, 2004, p. 217); automatic computer-generated feedback (Chen, 1997). The results confirmed that e-feedback gave a facilitative effect on revision. In other words, electronic feedback is more helpful. In addition, it is claimed that e-feedback aids learners emphasize on larger writing. The study focus is to elaborate on the learners' perceived of electronic feedback in writing multicultural classes using Edmodo. Therefore, the current study concerns with the three research questions: (1) how is learners' perception towards teacher electronic feedback in writing multicultural class using Edmodo at the English Department of IAIN Palangka Raya; (b) how is learners' perception towards peer electronic feedback; and (c) how is learners' perception on self-electronic feedback. In the study, the researcher applies the Edmodo class during the writing class. Edmodo is a simple mobilelearning tool to cover the lesson contents, materials, and instructions. It enables learners and 
teachers to interact online outside class (Hourdequin, 2014). Here, the researcher explores the learners' perception of the implementation of various models of electronic feedback in L2 multicultural writing class. In the study, perception refers to the degree of responses of the study sample on a perception scale of electronic feedback using Edmodo, and it may be positive, negative or uncertain. The fast changing of technology in education establishes a new spectrum of methods in which technology was involved in a classroom atmosphere. This emerges a mutual relationship between technology and Second Language Writing (SLW) in the idea of electronic feedback. Electronic feedback refers to automated feedback helped by a computer (Paige, Mark, Hyland, and Hyland, 2012, pp 105-122). The use of computers has become familiar in educational settings and is often liked by learners and teachers (Hyland, 2010). It has become familiar for teachers to require students to submit their papers electronically, like Edmodo class, and for teachers to provide feedback on learners' writing electronically. Studies on electronic feedback in SLW have been conducted by experts such as Liu and Sadler (2003), Schultz (2000), and Tuzi (2005). Their finding confirmed that Electronic feedback is more helpful for others. In line with them, some researchers also conducted a study on perception feedback e.g. Amara, 2015; Westmacott, 2017; Mahfoodh \& Pandian, 2011; Erkkilä, 2013; Tangkiengsirisin \& Kalra, 2016; and Chung, 2015. They suggested that learners perceived their teachers' feedback as helpful, very crucial for the language accuracy, and EFL learners had a strong interest in teacher comments, appreciated feedback and misinterpreted some teacher feedback comments. Different from the studies above, the researcher explores the learners' perceived of electronic feedback in writing multicultural classes using Edmodo at the English Department of IAIN Palangka Raya.

\section{Method}

The design in the study was descriptive research since the study focuses on investigating the learners' perceived on electronic feedback in writing multicultural classes using Edmodo. The study employed both qualitative and quantitative data. The instruments used in the study were closed-ended questionnaires, feedback analysis of learners' papers, and classroom observations.

\subsection{Participants}

This research was conducted at the English Department of IAIN Palangka Raya. The subjects of the study were the fourth-semester students. Meanwhile, the object of the study was electronic feedback in L2 writing. The participants consisted of 25 EFL learners (12 males and 13 females) with an average age between 20-21 years, participating in the Essay Writing class. This class consists of three big ethnic groups (Javanese, 8 students; Banjaresse, 5 students; and Dayaknese, 12 students).

\subsection{Procedures}

The data were obtained in 14 class meetings. All participants were assigned to join Edmodo learning to run the writing class. They should submit their writing products in Edmodo learning. Then, the teacher/ peer gave comments and suggestions using Edmodo learning. To answer the research questions about the learners' perceptions of feedback in L2 writing, the researcher distributed the questionnaire to the participants on Friday, June 1, 2018. 
The questionnaire was designed into two parts. The first part was to get demographical data, namely name, ethnic groups, age, gender, and email contact. The second part was to get data about the learners to perceive the three sources of electronic feedback (teacher, peer, and self). The second part consisted of 9 statements in the 5-point Likert Scale format. The data of this study were in the form percentage, words, sentences, or phrases to describe the learners perceived on electronic feedback in L2 writing multicultural class. The data were in both qualitative and quantitative ones. The data of quantitative dealt with the percentage of the learners perceived on electronic feedback in an L2 writing class. Meanwhile, the qualitative data dealt with a further explanation of the learners' perceived.

\section{Results}

This section presented participants perceive from questionnaire items related to the research question:how is the learners' perceived of electronic feedback in writing multicultural classes using Edmodo at the English Department of IAIN Palangka Raya. There were four major topics: (a) findings on learners' perception towards teacher electronic feedback; (b) findings on learners' perception towards peer electronic feedback; (c) findings on learners' perception on self-electronic feedback; and (d) findings on the most dominant source of feedback they prefer to receive.

\subsection{Learners Perception of Teacher Electronic Feedback}

The first objective of the study was to investigate the learners' perception of teacher electronic feedback. From questionnaire results, participants were asked about how their perceived-on teacher electronic feedback. Twenty-five participants responded, as illustrated in Table 1.

Table 1. Learners Perception of Teacher Electronic Feedback

\begin{tabular}{|c|c|c|c|c|c|c|c|c|}
\hline \multirow[t]{2}{*}{ No } & \multirow[t]{2}{*}{ Statements } & \multicolumn{2}{|c|}{ Dayaknese } & \multicolumn{2}{|c|}{ Banjarese } & \multicolumn{2}{|c|}{ Javanese } & \multirow[t]{2}{*}{ Total } \\
\hline & & Agree & $\begin{array}{c}\text { Not } \\
\text { agree }\end{array}$ & Agree & $\begin{array}{c}\text { Not } \\
\text { agree }\end{array}$ & Agree & $\begin{array}{c}\text { Not } \\
\text { agree }\end{array}$ & \\
\hline 1 & $\begin{array}{l}\text { I receive teacher electronic } \\
\text { feedback on language form } \\
\text { such as the correct use of } \\
\text { grammar, spelling, } \\
\text { punctuation, and } \\
\text { capitalization. }\end{array}$ & $\begin{array}{c}10 \\
(48 \%)\end{array}$ & $\begin{array}{c}2 \\
(8 \%)\end{array}$ & $\begin{array}{c}3 \\
(12 \%)\end{array}$ & $\begin{array}{c}2 \\
(8 \%)\end{array}$ & $\begin{array}{c}6 \\
(24 \%)\end{array}$ & $2(8 \%)$ & $\begin{array}{c}25 \\
(100 \%)\end{array}$ \\
\hline 2 & $\begin{array}{l}\text { I receive teacher electronic } \\
\text { feedback on content, such } \\
\text { as the unity of the ideas, } \\
\text { coherence of the ideas, } \\
\text { development of ideas, and } \\
\text { clarity of ideas. }\end{array}$ & $\begin{array}{c}9 \\
(36 \%)\end{array}$ & $\begin{array}{c}3 \\
(12 \%)\end{array}$ & $\begin{array}{c}3 \\
(12 \%)\end{array}$ & $\begin{array}{c}2 \\
(8 \%)\end{array}$ & $\begin{array}{c}5 \\
(20 \%)\end{array}$ & $\begin{array}{c}3 \\
(12 \%)\end{array}$ & $\begin{array}{c}25 \\
(100 \%)\end{array}$ \\
\hline \multirow[t]{2}{*}{3} & $\begin{array}{l}\text { I receive teacher electronic } \\
\text { feedback on organization } \\
\text { such as the introduction, } \\
\text { the body; or the conclusion. }\end{array}$ & $\begin{array}{c}10 \\
(40 \%)\end{array}$ & $\begin{array}{c}2 \\
(8 \%)\end{array}$ & $\begin{array}{c}5 \\
(20 \%)\end{array}$ & $\begin{array}{c}0 \\
(0 \%)\end{array}$ & $\begin{array}{c}6 \\
(24 \%)\end{array}$ & $2(8 \%)$ & $\begin{array}{c}25 \\
(100 \%)\end{array}$ \\
\hline & Total & $\begin{array}{c}29 \\
(39 \%)\end{array}$ & $\begin{array}{c}7 \\
(9 \%)\end{array}$ & $\begin{array}{c}11 \\
(15 \%)\end{array}$ & $\begin{array}{c}4 \\
(5 \%)\end{array}$ & $\begin{array}{c}17 \\
(23 \%)\end{array}$ & $\begin{array}{c}7 \\
(9 \%)\end{array}$ & $\begin{array}{c}75 \\
(100 \%)\end{array}$ \\
\hline
\end{tabular}


Table 1 (first-row table) demonstrated the participants' opinions on receiving teacher electronic feedback on language form. The second row demonstrated the participants' opinions on receiving teacher electronic feedback on content, such as the unity of the ideas, coherence of the ideas, idea development, and clarity of ideas. The third row demonstrated the participants' opinions on receiving teacher Electronic feedback on the organization such as the introduction, the body; or the conclusion. It could be stated that the majority of participants (39\% of Dayaknese students, $15 \%$ Banjarese students, and 23\% Javanese of students) felt that they received teacher feedback on language form, content, and organization.

In addition, based on computation results of Likert Scale, it was also found that Dayaknese, Banjarese, and Javanese students felt that they received teacher electronic feedback on language form, and on content, such as the unity of the ideas, coherence of the ideas, development of ideas, and clarity of ideas, and on organization such as the introduction, the body; or the conclusion, as described in Table 2.

Table 2. Likert Scale Results

\begin{tabular}{llllc}
\hline No. & Statements & Dayaknese & Banjarese & Javanese \\
\hline 1 & $\begin{array}{l}\text { I receive teacher electronic feedback on language } \\
\text { form such as the correct use of grammar, spelling, } \\
\text { punctuation, and capitalization. }\end{array}$ & 0.80 & 0.70 \\
2 & $\begin{array}{l}\text { I receive teacher electronic feedback on content, such } \\
\text { as the unity of the ideas, coherence of the ideas, } \\
\text { development of ideas, and clarity of ideas. }\end{array}$ & 0.74 & 0.80 & 0.95 \\
3 & $\begin{array}{l}\text { I receive teacher electronic feedback on organization } \\
\text { such as the introduction, the body; or the conclusion. }\end{array}$ & 0.80 & 0.85 & 0.90 \\
\hline
\end{tabular}

The results in Table 2 revealed that three items (items 1,2, and 3) related to three ethnic groups of learners' perception of teacher electronic feedback. According to the results, Dayaknese, Banjarese, and Javanese students mostly felt that they received teacher electronic feedback on the organization such as the introduction, the body; or the conclusion followed by language form and content. Most students (75\%) believed that it was important to receive teacher electronic feedback, arguing that it was the teacher's responsibility to give feedback for the learners' errors.

\subsection{Learners Perception of Peer Electronic Feedback}

The second objective was to explore the learners' perception of peer Electronic feedback. From questionnaire results, participants were asked about how they are perceived on peer Electronic feedback. Twenty-five participants responded, as illustrated in Table 3.

Table 3. Learners Perception of Peer Electronic Feedback

\begin{tabular}{llccccccc}
\hline No & \multicolumn{1}{c}{ Statements } & \multicolumn{2}{c}{ Dayaknese } & \multicolumn{2}{c}{ Banjarese } & \multicolumn{2}{c}{ Javanese } & Total \\
\cline { 3 - 7 } & Agree & $\begin{array}{l}\text { Not } \\
\text { agree }\end{array}$ & Agree & $\begin{array}{c}\text { Not } \\
\text { agree }\end{array}$ & Agree & $\begin{array}{c}\text { Not } \\
\text { agree }\end{array}$ & \\
\hline 1 & $\begin{array}{l}\text { I receive peer electronic } \\
\text { feedback on language form } \\
\text { such as the correct use of }\end{array}$ & $(28 \%)$ & $(20 \%)$ & $(16 \%)$ & $(4 \%)$ & $(28 \%)$ & $(4 \%)$ & $(100 \%)$ \\
& & & & & & & \\
& $\begin{array}{l}\text { grammar, spelling, } \\
\text { punctuation, and capitalization. }\end{array}$ & & & & & & & \\
& $\begin{array}{l}\text { I receive peer electronic } \\
\text { feedback on content, such as }\end{array}$ & $(32 \%)$ & $(16 \%)$ & $(20 \%)$ & $(0 \%)$ & $(20 \%)$ & $(12 \%)$ & $(100 \%)$ \\
\hline
\end{tabular}




\begin{tabular}{|c|c|c|c|c|c|c|c|c|}
\hline \multirow{3}{*}{3} & $\begin{array}{l}\text { the unity of the ideas, } \\
\text { coherence of the ideas, } \\
\text { development of ideas, and } \\
\text { clarity of ideas }\end{array}$ & & & & & & & \\
\hline & $\begin{array}{l}\text { I receive peer electronic } \\
\text { feedback on organization such } \\
\text { as the introduction, the body; } \\
\text { or the conclusion. }\end{array}$ & $\begin{array}{c}8 \\
(32 \%)\end{array}$ & $\begin{array}{c}4 \\
(16 \%)\end{array}$ & $\begin{array}{c}5 \\
(20 \%)\end{array}$ & $\begin{array}{c}0 \\
(0 \%)\end{array}$ & $\begin{array}{c}7 \\
(28 \%)\end{array}$ & $\begin{array}{c}1 \\
(4 \%)\end{array}$ & $\begin{array}{c}25 \\
(100 \%)\end{array}$ \\
\hline & Total & $\begin{array}{c}23 \\
(31 \%)\end{array}$ & $\begin{array}{c}13 \\
(17 \%)\end{array}$ & $\begin{array}{c}14 \\
(19 \%)\end{array}$ & $\begin{array}{c}1 \\
(1 \%)\end{array}$ & $\begin{array}{c}19 \\
(25 \%)\end{array}$ & $\begin{array}{c}5 \\
(7 \%)\end{array}$ & $\begin{array}{c}75 \\
(100 \%)\end{array}$ \\
\hline
\end{tabular}

Table 3 (first row) demonstrated the participants' opinions on receiving peer Electronic feedback on language form. The second row demonstrated the participants' opinions on receiving peer Electronic feedback on content, such as the unity of the ideas, coherence of the ideas, idea development, and clarity of ideas. The third row demonstrated the participants' opinions on receiving peer Electronic feedback on the organization such as the introduction, the body; or the conclusion. It could be stated that the majority of participants $(31 \%$ of Dayaknese students, $19 \%$ of Banjarese students, and 25\% Javanese students) felt that they received peer electronic feedback on language form, and on content, such as the unity of the ideas, coherence of the ideas, idea development, and clarity of ideas, and on organization such as the introduction, the body; or the conclusion.

In addition, based on the computation results of the Likert Scale, it was also found that Dayaknese, Banjarese, and Javanese students felt that they received peer electronic feedback on language form, as described in Table 4.

Table 4. Likert Scale Results

\begin{tabular}{lllll}
\hline No. & Statements & Dayaknese & Banjarese & Javanese \\
\hline 1 & $\begin{array}{l}\text { I receive peer electronic feedback on language form } \\
\text { such as the correct use of grammar, spelling, } \\
\text { punctuation, and capitalization. }\end{array}$ & 0.85 & 0.80 \\
2 & $\begin{array}{l}\text { I receive peer electronic feedback on content, such } \\
\text { as the unity of the ideas, coherence of the ideas, } \\
\text { development of ideas, and clarity of ideas. }\end{array}$ & 0.65 & 0.80 \\
3 & $\begin{array}{l}\text { I receive peer electronic feedback on organization } \\
\text { such as the introduction, the body; or the } \\
\text { conclusion. }\end{array}$
\end{tabular}

The results in Table 4 revealed that three items (items 1,2, and 3) related to three ethnic groups of learners' perception of peer feedback. According to the results, Dayaknese, Banjarese, and Javanese students mostly felt that they received teacher feedback on language form. Most students $(75 \%)$ believed that it was important to receive peer Electronic feedback, arguing that it was also the peer responsibility to give feedback for the learners' errors. Moreover, in the written interviews they said that it was important for the peer to revise their certain grammatical errors such as verb agreement, punctuation, and misspelling rather than their content.

\subsection{Learners Perception of Self- Electronic Feedback}

The third objective of the study was to elaborate on the learners' perception of selfElectronic feedback. From questionnaire results, participants were asked about how they are 
perceived on self- Electronic feedback. Twenty-five participants responded, as explained in Table 5.

Table 5. Learners Perception of Self-Electronic Feedback

\begin{tabular}{|c|c|c|c|c|c|c|c|c|}
\hline \multirow[t]{2}{*}{ No } & \multirow[t]{2}{*}{ Statements } & \multicolumn{2}{|c|}{ Dayaknese } & \multicolumn{2}{|c|}{ Banjarese } & \multicolumn{2}{|c|}{ Javanese } & \multirow[t]{2}{*}{ Total } \\
\hline & & Agree & $\begin{array}{c}\text { Not } \\
\text { agree }\end{array}$ & $\begin{array}{l}\text { Agre } \\
\text { e }\end{array}$ & $\begin{array}{c}\text { Not } \\
\text { agree }\end{array}$ & Agree & $\begin{array}{c}\text { Not } \\
\text { agree }\end{array}$ & \\
\hline 1 & $\begin{array}{l}\text { I receive self-feedback on } \\
\text { language form such as } \\
\text { spelling, punctuation, and } \\
\text { capitalization. }\end{array}$ & $\begin{array}{c}3 \\
(12 \%)\end{array}$ & $\begin{array}{c}9 \\
(36 \%)\end{array}$ & $\begin{array}{c}1 \\
(4 \%)\end{array}$ & $\begin{array}{c}4 \\
(16 \%)\end{array}$ & $\begin{array}{c}2 \\
(8 \%)\end{array}$ & $\begin{array}{c}6 \\
(24 \%)\end{array}$ & $\begin{array}{c}25 \\
(100 \%)\end{array}$ \\
\hline 2 & $\begin{array}{l}\text { I receive self-feedback on } \\
\text { content, such as the unity } \\
\text { of the ideas, coherence of } \\
\text { the ideas, development of } \\
\text { ideas, and clarity of } \\
\text { ideas. }\end{array}$ & $\begin{array}{c}3 \\
(12 \%)\end{array}$ & $\begin{array}{c}9 \\
(36 \%)\end{array}$ & $\begin{array}{c}1 \\
(4 \%)\end{array}$ & $\begin{array}{c}4 \\
(16 \%)\end{array}$ & $\begin{array}{c}2 \\
(8 \%)\end{array}$ & $\begin{array}{c}6 \\
(24 \%)\end{array}$ & $\begin{array}{c}25 \\
(100 \%)\end{array}$ \\
\hline 3 & $\begin{array}{l}\text { I receive self-feedback on } \\
\text { organization such as the } \\
\text { introduction, the body; or } \\
\text { the conclusion. }\end{array}$ & $\begin{array}{c}5 \\
(20 \%)\end{array}$ & $\begin{array}{c}7 \\
(28 \%)\end{array}$ & $\begin{array}{l}5 \\
(20 \\
\%)\end{array}$ & $\begin{array}{c}0 \\
(0 \%)\end{array}$ & $\begin{array}{c}4 \\
(16 \%)\end{array}$ & $\begin{array}{c}4 \\
(16 \%)\end{array}$ & $\begin{array}{c}25 \\
(100 \%)\end{array}$ \\
\hline & Total & $\begin{array}{c}11 \\
(15 \%)\end{array}$ & $\begin{array}{c}25 \\
(33 \%)\end{array}$ & $\begin{array}{c}7 \\
(9 \%) \\
\end{array}$ & $\begin{array}{c}8 \\
(11 \%)\end{array}$ & $\begin{array}{c}8 \\
(11 \%)\end{array}$ & $\begin{array}{c}16 \\
(21 \%)\end{array}$ & $\begin{array}{c}75 \\
(100 \%)\end{array}$ \\
\hline
\end{tabular}

Table 5 demonstrated the participants' opinions on receiving self-Electronic feedback on language forms such as the correct use of grammar, spelling, punctuation, and capitalization. It showed that all ethnic students did not agree to the statement that they received self-Electronic feedback on language form; on content, such as the unity of the ideas, coherence of the ideas, development of ideas, and clarity of ideas; and an organization such as the introduction, the body; or the conclusion. The majority of participants (33\% of Dayaknese students, $11 \%$ of Banjarese students, and $21 \%$ Javanese students) felt that they did not get self-feedback on language form, and on content, such as the unity of the ideas, coherence of the ideas, development of ideas, and clarity of ideas, and on organization such as the introduction, the body; or the conclusion. The result of the computation of the Likert Scale indicated that learners did not receive self- feedback on language form, content, and organization, as described in Table 6.

Table 6. Likert Scale Results

\begin{tabular}{|c|c|c|c|c|}
\hline No. & Statement & Dayaknese & Banjarese & Javanese \\
\hline 1 & $\begin{array}{l}\text { I receive self-feedback on language form } \\
\text { such as the correct use of grammar, } \\
\text { spelling, punctuation, and capitalization. }\end{array}$ & 0.40 & 0.40 & 0.45 \\
\hline 2 & $\begin{array}{l}\text { I receive self-feedback on content, such as } \\
\text { the unity of the ideas, coherence of the } \\
\text { ideas, development of ideas, and clarity of } \\
\text { ideas. }\end{array}$ & 0.30 & 0.40 & 0.50 \\
\hline 3 & $\begin{array}{l}\text { I receive self-feedback on organization } \\
\text { such as the introduction, the body; or the } \\
\text { conclusion. }\end{array}$ & 0.35 & 0.30 & 0.40 \\
\hline
\end{tabular}


The results in Table 6 revealed that three items (item 1,2, and 3) related to three ethnic group of learners' perception of peer feedback. According to the results, Dayaknese, Banjarese, and Javanese students mostly felt that they did not receive self-feedback on language form, content, and organization. Most students believed that self-feedback was not too important to improve their language development, arguing that they did not get benefits from self- feedback because they were not sure to the errors they revised. The EFL learners were also asked to give comment on how they got benefits from the feedback of the teacher. A few students said that they got benefits from the teacher's feedback, in increasing grammar accuracy and others said that they got benefits on organization and content improvement, as said by some respondents. The students were also given a question on their preference about the way the teacher corrected their linguistic errors. Most L2 learners preferred to the texts, because it was easier to understand the errors. To sum up, the learners' interviews suggested that they appreciated teacher electronic feedback and revised of their work. The EFL learners claimed that they got benefit from teacher feedback on language forms.

The results in Table 6 revealed that three items (items 1,2, and 3) related to three ethnic groups of learners' perceptions of peer feedback. According to the results, Dayaknese, Banjarese, and Javanese students mostly felt that they did not receive self-feedback on language form, content, and organization. Most students believed that self-feedback was not too important to improve their language development, arguing that they did not get benefits from self- feedback because they were not sure to the errors they revised. The EFL learners were also asked to give comment on how they got benefits from the feedback of the teacher. A few students said that they got benefits from the teacher's feedback, in increasing grammar accuracy and others said that they got benefits on the organization and content improvement, as said by some respondents. The students were also given a question on their preference about the way the teacher corrected their linguistic errors. Most L2 learners preferred to the texts because it was easier to understand the errors. To sum up, the learners' interviews suggested that they appreciated teacher electronic feedback and revised their work. The EFL learners claimed that they got benefit from teacher feedback on language forms.

The findings of learners and teachers' perceived towards Electronic feedback dealt with three issues such as learners' attitudes towards their teachers, peer, and self- Electronic feedback. First, the findings demonstrated most students $(80 \%)$ said that it was needed to receive teacher Electronic feedback, arguing that it was the responsibility of the teacher to give feedback for the learners' errors. Second, most students $(68 \%)$ believed that it was also important to receive peer Electronic feedback, arguing that it was also the peer responsibility to give feedback for the learners' errors. Third, most students $(75 \%)$ believed that selffeedback was not too important to improve their language development, arguing that they did not get benefits from self- feedback because they were confused to the errors they revised.

Responses also showed that learners appreciated the teacher's electronic feedback. The process of giving electronic feedback took two times for each learners' composition. The teacher followed up students after giving electronic feedback and students revised the draft after receiving feedback. Then, they wrote a second draft to be corrected by their peers. Finally, learners were assigned to write the final draft. The study revealed that L2 learners had a positive attitude towards Electronic feedback. Although they expressed a positive attitude towards Electronic feedback, learners indicated their preference only for certain techniques. Learners' responses showed their preference for direct Electronic feedback. Learners considered direct electronic feedback was helpful and useful for them. The learners also agreed that direct electronic feedback was helpful and useful for learners' improvement in writing. 
To conclude, the learners' responses showed a positive perception of Electronic feedback. They affirmed that feedback was useful in L2 writing. However, learners preferred teacherdirect electronic feedback to correct their errors than others. In general, learners assumed that Electronic feedback improved writing skills, especially on grammar accuracy and organization. The current study supports previous studies that students tend to make revisions where they receive feedback (electronic or written) (Ferris, 2006; Martin-Beltran \& Chen, 2013; Tuzi, 2005). Direct, explicit e-feedback, which is preferred by both teachers and students, is effective whether it was handwritten or electronic feedback (Baker and Bricker, 2010; Bitchener, 2008; Bitchener \& Knoch, 2008; Ellis, Loewen, \& Erlam, 2006; Ellis, Sheen, Murakami, \& Takashima, 2008; Ellis, 2009; and Sheen, 2007).

The results were also in accordance with (Hamouda, 2011). She revealed that nearly half of the students preferred direct feedback and it assisted them to identify their errors and improve their accuracy in writing. As previous research showed Ferris (2002) teachers should use a variety of feedback and correct various errors. Sometimes the focus should be on different types of errors and sometimes focus on certain grammatical or lexical errors. In contrast, students preferred when teachers focus only on specific types of errors, rather than correcting all errors in their work. This finding, in terms of learners' perceived towards teachers'electronic feedback, was in accordance with Amara (2015) about learners' perceptions of teacher feedback. She revealed that L2 learners had a strong interest in teacher comments, appreciated feedback and misinterpreted some teacher feedback comments. This finding was also in line with Ferris (2004) stating that most students need and want to be corrected by their teachers; therefore, error correction cannot be excluded from L2 writing classrooms. In Chandler (2003)'s study, based mostly on corrections and rewriting, he concluded that teachers should give error correction feedback and require students to make the correction.

All in all, the findings of the study were in accordance with Mahfood \& Pandian (2011), Orts Soler (2015), Ferris \& Roberts (2001), Bitchener \& Knoch (2010), Lee (2008), Treglia (2008), Schulz (2001), Elwood \& Bode (2014), and Song, Hoon, \& Alvin (2017). Here, the students and teacher's responses showed a positive perception of feedback. The learners preferred to teacher-direct feedback to correct their errors. Meanwhile, the teacher preferred to use various feedback depending on the learners' level. In general, all learners believed that Electronic feedback improved writing skills, especially on grammar accuracy and organization.

\section{References}

[1] Amara, M.: Learners' perceptions of teacher written feedback commentary in an ESL writing classroom. International Journal of English Language Teaching. The University of Zawia Libya. Vol 3, pp. 38-53 (2015)

[2] Baker, W and Bricker, R H.: The effects of direct and indirect speech acts on native English and ESL speakers' perception of teacher written feedback. System, Vol 38 (1). pp. 75-84 (2010)

[3] Bitchener, J.: Evidence in support of written corrective feedback. Journal of Second Language Writing, Vol 17 (2). pp 102-118 (2008)

[4] Bitchener, J and Knoch U.: The value of written corrective feedback for migrant and international students. Language Teaching Research, Vol 12 (3), pp 409-431 (2008)

[5] Bitchener, J and Knoch U.: The contribution of written corrective feedback to language development: A ten-month investigation. Applied Linguistics, Vol 31 (2), pp 193-214 (2010)

[6] Chandler, J.: The efficacy of various kinds of error feedback for improvement in the accuracy and fluency of L2 student writing. Journal of Second Language Writing, Vol 12 (3), pp 267-296 (2003) 
[7] Chen, J.: Computer generated error feedback and writing process. TESL EJ, (1997)

[8] Chung, B.: Written corrective feedback: The perception of Korean EFL learners. Journal of PanPacific Association of Applied Linguistics, Vol 19 (2), pp 75-88 (2015)

[9] Ducken, R.: Written feedback in the L2 writing classroom. EWU Masters Thesis Collection (2014)

[10] Ellis R, Sheen Y, Murakami M and Takashima, H.: 2008.The effects of focused and unfocused written corrective feedback in an English as a foreign language context. System, Vol 36 (3), pp 353-371 (2008)

[11] Ellis, R.: 2009 A typology of Electronic feedback types. ELT Journal, Vol 63 (2), pp 97-107 (2009)

[12] Ellis R, Loewen S and Erlam R.: Implicit and explicit feedback and the acquisition of L2 grammar. Studies in Second Language Acquisition, Vol 28 (2), pp 339-368 (2006)

[13] Elwood, J and Bode, J.: 2014 Student preferences vis-à-vis teacher feedback in university EFL writing classes in Japan. System, Vol 42 (1), pp 333-343 (2014)

[14] Erkkilä, M.: Teacher written feedback: Teachers' perceptions of given feedback. University of Jyväskylä, Department of Languages English (2013)

[15] Ferris, D and Roberts, B.: 2001 Error feedback in L2 writing classes how explicit does it need to be?. Journal of Second Language Writing, Vol 10 (3), pp 161-184 (2001)

[16] Ferris, D.: 2006 Does error feedback help student writers? New evidence on the short- and longterm effects of written error correction. In Feedback in second language writing: contexts and issues, pp 81-100 (2006)

[17] Ferris, D.: 2002 Treatment of error in second language writing classes. Ann Arbor, University of Michigan Press (2002)

[18] Ferris, D.: 2004 The "Grammar Correction" Debate in L2 Writing: Where are we, and where do we go from here? (and what do we do in the meantime ...?). Journal of Second Language Writing, Vol 13 (1), pp 49-62 (2004)

[19] Goo, J and Mackey, A.: Feedback, individual variation in cognitive capacities, and L2 development: Recasts vs. metalinguistic feedback. Department of Linguistics (2011)

[20] Hamouda, A.: A Study of Students and Teachers' Preferences and Attitudes towards Correction of Classroom Electronic Errors in Saudi EFL Context. English Language Teaching, Vol 4 (3), (2011)

[21] Hourdequin, P.: Edmodo: A simple tool for blended learning. The Language Teacher, Vol 38 (1) (2014)

[22] Hyland, F.: Future directions in feedback on second language writing: Overview and research agenda International Journal of English Studies, Vol 10 (2), pp 171-182 (2010)

[23] Lee, I.: Student reactions to teacher feedback in two Hong Kong secondary classrooms. Journal of Second Language Writing, Vol 17 (3), pp 144-164 (2008)

[24] Li, S.: The effectiveness of feedback in SLA: A Meta-Analysis. Language Learning (2010)

[25] Liu, J and Sadler, R.: The effect and affect of peer review in electronic versus traditional modes on L2 writing. Journal of English for Academic Purposes, Vol 2, pp 193-227 (2003)

[26] Mahfoodh, O and Pandian, A.: 2011 A qualitative case study of EFL learners' affective reactions to and perceptions of their teachers' electronic feedback. English Language Teaching, Vol 4 (3), (2011)

[27] Martin-Beltran, $M$ and Chen, P.: from monologue to dialogue: A case study on mediated feedback in a transnational asynchronous online writing tutorial. Academic Exchange Quarterly, Vol 17 (1), pp 145-150 (2013)

[28] Orts Soler, S.: EFL learners' attitudes and preferences towards electronic feedback (2015)

[29] Paige D Ware, Warschauer M, Hyland K and Hyland F.: Electronic feedback and second language writing. Cambridge University Press (2012)

[30] Prins F, Sluijsmans D, Kirschner P and Strijbos J.: 2005 Formative peer assessment in a CSCL environment: A case study Assessment \& Evaluation in Higher Education, pp 417-444 (2005)

[31] Russell, J and Spada, N.: The effectiveness of feedback for the acquisition of L2 grammar. Synthesizing Research on Language Learning and Teaching, pp 133-164 (2006) 
[32] Saito, K and Lyster, R.: Effects of form-focused instruction and feedback on L2 pronunciation development of /r\{turned\}/ by Japanese Learners of English. Language Learning, Vol 62 (2), pp 595-633 (2012)

[33] Sheen, Y.: The effect of focused written corrective feedback and language aptitude on ESL learners' acquisition of articles. TESOL Quarterly, Vol 41 (2), pp 255-283 (2007)

[34] Schulz A 2001 Cultural differences in student and teacher perceptions concerning the role of grammar instruction and corrective feedback: USA-Colombia Modern Language Journal 85(2) pp 244-258.

[35] Song G, Hoon L and Alvin L.: Students' response to feedback: an exploratory study. RELC Journal (2017)

[36] Tangkiengsirisin, S and Kalra, R.: Thai students' perceptions on the direct vs. indirect written corrective feedback: A Thai university context. Arab World English Journal (AWEJ), Vol 7 (33), pp 161-176 (2016)

[37] Treglia, M.: 2008 Feedback on feedback: Exploring student responses to teachers' written commentary. Journal of Basic Writing, Vol 27 (1), pp 105 (2008)

[38] Tuzi, F.: The Impact of E-feedback on the revisons of L2 writers in an academic writing course. Elsevier, pp 217-235 (2004)

[39] Tuzi, F.: The impact of e-feedback on the revisions of L2 writers in an academic writing course. Computers and Composition, Vol 21 (2), pp 217-235 (2005)

[40] Westmacott, A.: Direct vs. indirect written feedback: Student perceptions. Íkala, Revista de Lenguaje y Cultura, Vol 22 (1), pp 17-32 (2017) 